\title{
(De)politicization of COVID-19 Pandemic in the Implementation of 2020 Simultaneous Regional Elections
}

\author{
Yuseptia Angretnowati ${ }^{1}$, Palupi Anggraheni ${ }^{2}$ \\ ${ }^{1}$ Department of Communication Science, Faculty of Social and Political Science UPN "Veteran" Yogyakarta, \\ Sleman Regency 55283 \\ yuseptia_angretnowati@upnyk.ac.id \\ ${ }^{2}$ Department of International Relations, Faculty of Social and Political Science UPN "Veteran" East Java, \\ Surabaya City, 60294 \\ palupi.anggraheni.hubint@upnjatim.ac.id
}

Received: 14/01/2021.

Reviewed: 24/02/2021.

Published: 28/04/2021

Copyright $\odot 2021$ by the author (et al) and Jurnal

Sosial Humaniora (JSH)

*This work is licensed under the Creative Commons Attribution International License (CC BY 4.0). http://creativecommons.org/licenses/by/4.0/

\section{Subject Area: Politics}

\begin{abstract}
Coronavirus disease (COVID-19) takes effect on state management in Indonesia. Good crisis management is necessary to mitigate COVID-19. This research uses Beland 's conceptual framework on politics of insecurity and its implementation on the state's management crisis process, especially on how the state protects its citizens towards non-traditional threads while performing political accountability. The 2020 Simultaneous Regional Election (Pilkada) during pandemic is positioned as a case study, especially on how policy conflicts and calculation of benefits-risks occur. It has a pivotal role in establishing perception of collective thread. In the case of 2020 Simultaneous Regional Election, conflict in policy creates social anxiety and political tension caused by a health crisis. This research finds that the government (de) politicized the 2020 Simultaneous Regional Elections by using a repertoire of types of strategies, i.e: avoiding blame and claiming credit, which were carefully compiled and implemented in a specific frame.
\end{abstract}

Keywords: accountability; state protection; politics of insecurity; COVID-19; 2020 simultaneous regional elections; (de)politicization; blame avoidance; credit claiming

\section{Introduction}

The Coronavirus disease (COVID-19) pandemic has impactful effects on state affairs, especially in the strategy taken to respond to its the primary and secondary impacts. World Health Organization announced the COVID -19 outbreak as a pandemic on March 11, 2020, based on recorded infection which reached more than 118,000 cases in more than 110 countries (Dhucarme, 2020). The status of a pandemic makes COVID a global threat, whom affects almost all aspects of human life, especially in human movement restriction

The response of countries in the world regarding this relatively new outbreak has also varied. Policies that lead to restrict people movement are interpreted in various ways according to the preferences of policy makers in each country. Several countries that are considered successful in controlling the spread of COVID19, such as Japan, South Korea and Italy, have prioritized a combination of the roles of the health sector and the state's apparatus as the main actors in the crisis management strategy in handling COVID-19. Apart from 
that, political leadership, collective memory of similar experiences, and knowledge of epidemic control are also become a determinant in the success of COVID-19 mitigation. For example, Japan's readiness factor in implementing disaster mitigation (risk culture) in the face of COVID-19, which is characterized by clear risk communication and an awareness of being responsible for one's own safety, can be linked to the historical aspects of Japan which have a long history of dealing with disasters (LIPI, 2020).

COVID-19 pandemic has a fairly complex dimension since it restricted human social interaction. Besides, there is constant debate whether health interests will jeopardize economic interest vice versa. In fact, different response of global pandemic management policies depends on several factor such as political leadership, collective memory of similar experiences, and data management. Several countries that focus on the health sector as a crisis management strategy in handling COVID-19 are Japan and Vietnam (Yanuarti, 2020). Unfortunately, Indonesia's response is slower than its counterparts and thus missed many important moments in suppressing COVID-19's case. Several ongoing evaluations show that the policy for handling COVID-19 in Indonesia has a vague focus, creates controversy, and the latest analysis is that the new normal policy has the potential to create a shift in power relations, class consolidation, and inequality (Lay, 2020). In the other hands, the COVID-19 pandemic is a new landscape that has sparked new insecurity for society at large - and more specifically for minorities (Carlà, 2020), the response to COVID-19 has been "the politics of security - or rather, securitization" (Sears, 2020).

Based on explanation above, this research will try to focus on what factors whom influence the government's decision to hold 2020 Simultaneous Regional Elections amidst policy conflicts during the pandemic? This article aims to explore and build literature on the politics of insecurity embedded in the COVID-19 pandemic. The second objective will explore how political leaders and other political elite actors carry out political strategies in carrying out the politics of accountability during the pandemic, especially in the case of regional election policies in the midst of a pandemic. This research then focuses on the decisionmaking process and policies during COVID-19 Pandemic which according to public policy studies, brought policy systems into unusual stage. The discussion is related in the corridor of crisis management with the human security policy paradigm. Since COVID-19 pandemic has also affected social system performance which produced various public policies clash and created potential policy conflict. As stated by Brändström \& Kuipers (2003), policy conflicts are prevalent when the whole society is affected by certain cause and needs an immediate response and accountability. In this condition, a spectrum of political psychology is formed from policy actors or other interest actors and started to implement framing politics and blame. The objectives of this research is not only emphasize on discursive political patterns carried out by policy actors in the three dimensions of political framing, but also bringing empirical studies through the momentum of political events in the pandemic era in Indonesia. Through the inductive method, this research also begins to examine how far three determinants factor: individuals, institutions, culture, and situation affect public perception and eventually lead to the politics of framing and blaming. 


\section{Literature Review}

\section{Human Security and Biopolitics/ The Humanitarian Case for Delaying Elections}

In this section the author will focus on explaining two main arguments, (i) the relationship between state responses in pandemic management from a global perspective associated with the concept of human security and (ii) how far apolitical conditions such as humanitarian factors dominate policymaking as a form of political response from domestic perspective.

The concept of human security is rooted in both security studies and strategic studies in international relations, focuses on the argument about the importance of human being as significant entities that must be protected ad centered in any form of security questions (Roberts, 2009). Besides, it also intertwined with the concept of non-traditional security by widening the scope of "threats" with seemingly apolitical entities, from climate change, sustainable development, nuclear weapons the health crisis. While positioned human security with global governance framework, concept of biopolitics is laid alongside with the urgencies of "cooperation beyond state power to mitigating some of their most abhorrent effects" (Roberts, 2009). COVID-19 pandemic has shifted the definition of security by positioned a health crisis as a potential threat to human survival. The reinterpretation of COVID-19 as a non-traditional threat can be seen in the policies of several countries that have officially changed the orientation of US security policies, including crisis management and reformulation of the global health design (Nurhasanah, 2020).

Before the COVID-19 pandemic, several studies showed that the power of the state had decreased. Globalization and interdependence strengthen the role of non-state actors alongside with the decreasing state influence. Foucault in Kapolkas introduces the term of biopolitics as "a shift from (events) that were originally biological to develop into something political" (Kalpokas, 2020). Thus, according to Foucault, the dynamics of power also occur in events that appear biological but also have socio-political consequences. COVID-19 pandemic occurred creates power struggle and can be examine from how state create policies controlling citizen's daily life. In this condition, the role of the state, which previously seemed to weaken due to the increasingly connected global community, seems gaining its authoritative role again. Several policies in pandemic era, such as social restrictions and data surveillance, supported the argument that the role of the state as the highest political authority in a region, are getting stronger.

Furthermore, how the state responds to a seemingly apolitical and makes it as the basis of political policy can be found in literature studies that discuss the delay of general elections due to humanitarian reasons. Election administration is one of the important features in the administration of a democratic country. However, election administration has experienced delays due to certain conditions such as natural disasters or health crises. Humanitarian factors became a force majeure which powerful enough in defeating the urgency of holding elections (James \& Alihodzic, 2020). Furthermore, James \& Alihodzic stated that although this condition is theoretically justified, further consequences such as the integrity of the election administration, the readiness of supporting bodies such as the judiciary, legislative and executive sectors must be examined. Otherwise, if the state still decides to hold elections during a humanitarian crisis, it will affect the process, 
participation, and the final outcome of the political event unless the government is ready with sufficient support system.

\section{Political Insecurities, towards Threat Infrastructure and (De)politization}

In this section several literature studies from sociology and political science in order to understand politics of insecurity. Daniel Beland (2007), systematically brings the concept and creates a framework for a more comprehensive understanding of this study. Daniel Béland was inspired by Ulrich Beck's thoughts on the "Risk Society" whom mentioned first about the existence of acute risks that characterized our current history as human being in modern life and secondly, the concept of "organized irresponsibility" which stated an important fact that elected officials often become target whom should be responsible when a bad event happens even if sometimes it was beyond their control.

When public attention is high and creating impactful effect toward society, accordingly in sociopsychology aspect the interested authority will respond it politically. According to Beland (2007) by referring Beck's (1992) mentioned that every exercise of power, including in the discourse of a collective insecurity, its effectiveness is determined by threat infrastructure which is shaped by the structural and construction aspects of threats faced by citizens and political leaders. Then, political authorized will construct the collective thread to support their political agenda.

It should be understanding that crisis could lead into the accumulation of negative emotion, insecurities and increased demand from public in questioning the responsibility of government 's ability in mitigate the crisis (Brändström \& Kuipers, 2003). In the fragment of cognitive characteristics in policy conflicts, policy actors carry out discursive process activities, such as rhetorical actions by politicizing and depoliticizing ((de) politicization). These two actions is defined as an efforts to present or eliminate politics as an inherent agency when formulating public policy agenda. Furthermore, (de) politicization process is being achieved by constructing framing and blaming politics. As a political phenomenon, blame games carried out by political authorities during crisis caused by the COVDI-19 pandemic have attracted the attention of academics such as Matthew Flinders, Hanif, and Zahariadis et al., (2020).

\section{Methodology}

This research uses literature review a with qualitative approach. As stated by Creswell (1994 in Denney $\&$ Tewksbury, 2013), it emphasizes on an in-depth reading of research results that are closely related to the conducted research, i.e. political insecurities at public policy sphere (Fraenkel \& Wallen, 1990) As a research method, literature review also focused on sustainability of a certain major topic in current literature and tried to fill the gap from previous research (Marshall \& Rossman, 2016). In this research, the effect of COVID-19 is not positioned in epidemiologic perspective but being categorized in social politic studies since it potentially brings social conflict and included in the area of general election governance policies. Data is collected through various sources, such as journal books, document and website. 


\section{Discussion}

\section{Elections in the Era of Pandemic and Collective Fear: Human Security vis a vis Upholding Democracy}

At least there are two literature approaches to explain how far the implementation of election during pandemic could be problematic. First, by following political and security framework from International Relations scholar such as Buzan et al., (1998). The second approach is following conceptual framework from Sociology and Politic Science such as Beland (2007) whom inspired by Ulrich Beck's Risk Society and then developing conceptual framework related to Political Insecurity.

Security studies perspective provides comprehensive analytics on how COVID-19 pandemic has been risen globally and forced states to create suitable policy. It reflects heavily on political security or securitizations. According to Buzan et al., (1998), a glimpse definition on how far security issue became highly politized is:

"... the move that takes politics beyond the established rules of the game and frames the issue... as an existential threat, requiring emergency measures and justifying actions outside the normal bounds of political procedure.“( Sears, 2020).

Sears positioned COVID-19 in securitizations by unraveling several components, such as the referent object(s), securitizing acts, and emergency measures are manifested. The presence of political insecurity complements security perspective, especially in exploring political leader's effort to establishing a certain social construction to create collective insecurity. This effort is important to emphasize there is a concrete role of political leaders in facing COVID-19. How COVID is perceived as new global can be examined from US President Trump's decision to declare it as a national emergency and positioned it as a threat to national security as well as President Joko Widodo's decision when stipulating Presidential Decree 12/2020 regarding the Spreading of COVID-19 as Non-natural Disaster. Meanwhile upholding democracies by ensuring an election is held during pandemic human security faced conceptual complexity since it may jeopardize human safety.

Meanwhile in the context of collective insecurities, Béland traces what lies behind political leader's motive in choosing political insecurities. It is similar with social construction in securities studies that certain policies is a way to communicate with citizen and "imposing fear to them" (Glassner 1999; Furedi 2002 in Béland, 2010) . Later, Béland also found that there is a process that must be followed to understanding of the meaning of a political strategy, since politicians tends to meticulously calculate all the risks and possibilities of every political step taken. In line with the four main objectives of politics or the arena of competition as described by Bourdieu (1991 in Buzan et al., 1998), the strategy adopted by politicians is a consequence of liberal democracy.

Based on this logic, there are two determinants' factors in constructing collective fear in strategic politic, i.e. political institutions /policy legacies and agenda setting and framing processes. The first determinant hopefully will be able to interpret "policy feedback" dan "vested interest". Both will affect all object of national protection. It can be concluded that every policy will be influenced by strong personal interest and affected political insecurities and state protections. How these two categories influenced political strategy of authorized political actors will be explained in the next sections. 


\section{Political Institutionalization}

The discussion of institutionalization aspects of election policy is being specified in designing an election administration in current political developments. Regular elections are one of the most important events in determining the future of democracy. The presence of the COVID-19 pandemic brings new challenges on in holding general elections around the world. James \& Alihodzic (2020) wrote one of the latest researches with the title "When Is It Democratic to Postpone an Election? Elections During Natural Disasters, Covid-19, and Emergency Situations". It highlights the lack of literature or research that examines cases of postponement of elections during emergency situations, apart from other critical characteristics such as democracy, peace and security's perspective. James \& Alihodzic (2020) deliberately open the question by offering conceptual benchmarking on whether an election should be held or not during pandemic by offering substantive democracy theory.

James \& Alihodzic also added, the requirements for holding democratic elections if they are carried out regularly and periodically (Dahl 1971; Przeworski 1999 in James \& Alihodzic, 2020). This perspective on democratic elections is enshrined in Article 21 (3) of the Universal Declaration of Human Rights (UN General Assembly 1948), furthermore, this kind of meaning has been widely adapted into the concept of elections with integrity (Norris 2014). So that when the COVID-19 pandemic has the potential to pose a major threat to human life and security, if the election does not take place, it also has crucial interests. By remain adaptive to the situation and maintains integrity became the a sustain plan in this period and thus requires careful preparation starting from the rule making process.

As an important parameter for consideration to the authorized institution regarding holding elections during pandemic, a report is made by the Institute for Democratic and Electoral Assistance (IDEA) has monitored the implementation of elections around the world. It shows the presentation of elections during the pandemic period from February to December 2020 around 50\% (185 electoral processes) held elections on schedule, 27\% (93 electoral processes) postponed and then held the event, and 23\% (92 electoral processes) decided to postpone. In addition, IDEA (2020) shows democratic countries are more likely postponing their elections compared to countries with non-democratic (authoritarian) regimes (IDEA, 2020).

The COVID-19 pandemic has also caused complications in organizing elections, IDEA has summarized several issues that pose a serious threat to democratic institutionalization and concludes that the sustainability of these factors can lead to significant complications and operational delays and can trigger or deepen political conflict such as difficulties in logistic and administration and maintaining integrity; voter turnout is higher during holiday and public movement restrictions policy; changes in the public policy agenda, from political party manifestos to policies that focus on major issues or events and the last is political polarization caused by differences in views between postponing or holding elections, which eroded the legitimacy of political leaders (IDEA, 2020).

2020 Simultaneous Regional Election is the second election has been held after issuance of Law no. 1/2015 concerning to the stipulation of Government Regulation in Lieu of Law (Perppu) No. 1/ 2014 
concerning of the Election of Governor, Regent, and Mayor Election becomes the legal basis for the policy of regional elections in Indonesia. During COVID-19 pandemic, Indonesian Government decided to postpone the election from September $23^{\text {rd }}, 2020$ to December $9^{\text {th }} 2020$. The government's decision refers to Perppu No.2 of 2020 which was later stipulated in Law No.6 of 2020, which contains two considerations, i.e: health considerations and domestic political stability. It was supported by President Joko Widodo's argument as head of state by emphasizing that the decision for Regional Election is unavoidable to ensure the citizen constitutional rights to vote and being voted in Regional Elections (CNN Indonesia, 2020). Whether the real motives in postponed 2020 Regional Elections remain unknown, it shows two policy contexts that contradict each other's logic of interest i.e: the health and safety of humanity and the values and principles of democratization. Therefore, providing an in-depth analysis of political institutionalization of certain policy areas that become policy issues, especially in electoral governance is necessary.

Simultaneous Regional Election on $9^{\text {th }}$ December 2020 was decided through hearing meeting with Commission II of the People's Representative Council (DPR) alongside with Minister of Home Affairs, National Commission of General Elections (KPU), General Election Supervisory Agency (Bawaslu) and Higher Council of Election Commissioner (DKPP). Several member from the legislative is reported against the Minister of Home Affairs decision in continuing elections such as Syamsurizal El Walid (from Partai Persatuan Pembangunan), Johan Budi S. Pribowo (from F-Partai Demokrasi Indonesia Perjuangan), Sukamto from F-Partai Kebangkitan Bangsa (PKB), and Aminurokhman from F-Partai NasDem proposed option in March 2021 and Cornelis and Endro Suswantoro Yahman (from F-PDIP) and Kristiana Mukti from F-Partai NasDem choose September 2021 (Amalia, 2020).

Through policy feedback, political actors will learn the landscape and asses their capacity and interest (Huysmans, 2006). As direct product of local autonomy, it becomes the important mechanism in ensuring leadership succession in the future of democratization in regional political level. There was a good record in 2017 and 2018 Regional Election when the participation rate was high around 70\% (Fernandez, 2020) and thus can be manifested as a support for continuity for the previous policy. But the emergence of COVID-19, increased the demands from civil society for the government to establishing legal framework for regional election whom produce adaptive leader for every situation (Priyasmoro, 2020). Thus, the government is urged to fix the current regulation whom hopefully accommodate humanitarian aspect and public interest whom depends on the interest and political willingness among actors and how far the crisis' damage is managed (Huysmans, 2006). But this article is not intended to explore more about this problem, but rather focused on how far the government's ability to immediately provide legal framework related to the 2020 Simultaneous Regional Elections (Karim, 2020).

\section{Infrastructure of Insecurity: Structural and Constructional}

The emergence of COVID-19 increased the understanding of various political leadership in crisis era. Several leaders, especially the populist one, try to securitize this issue and can be interpreted as a process of calculating and rationalizing its benefit (Sears, 2020). The objectives of securitization are the public acceptance 
of state decision to impose an extradentary act. Buzan et al., (1998) reminds us that every act of securitization has political risk such as State excessing use of power by jeopardizing individual freedom.

Similar with securitization who use external threat as a framing strategy to rationalize State's extraordinary protection, threat infrastructure also uses political insecurities of leader as one of strategy in creating collective fear and use it as a tool to change policy orientation. Structural and constructed threat is used to examine how far threat infrastructure is constructed. Structural threat usually characterized as a latent and low politic whom not considered as main threat for human existence yet. Every form of structural threat has obstacles and opportunities that political leaders will consider. However, this structural element also does not escape the framing process which affects the perception of collective threat thinking. Meanwhile, constructed threat is formed by the logic of political leader. Both threats are configured in a "threat infrastructure" which provides an analytical framework regarding the complex relationship between the structural and construction aspects of threats, both faced by ordinary citizens and political leaders. "Threat infrastructure" is also a pointer to the concrete characteristics of each collective threat in a particular policy area.

Polarization of policies and conflict between postponing and holding elections during a pandemic is inevitable since it stands firmly between two rationale: politics (democracy) and health policy. When WHO's call for adapting the "new normal" life as a survival strategy amid the COVID-19 pandemic has brought about changes in social, political and economic life. The decision to hold election is an effort to achieve secure elections process with integrity. However, despise the effort, the elections still has some serious structural problems Lay (2020), explaining that without being supported by policy reorientation and the formation of new norms after COVID-19 will lead to new power relations. The same abstract was produced by Carlà (2020), how this pandemic has had a more impact especially on minorities, such as immigrants whose conditions are increasingly marginalized in border security issues, economic inequality has implications for injustice to needed health services, and the stigma of being "super carries "to people who are socially and politically marginalized, this condition occurs in many countries which are led by populist politicians.

Class injustice issues caused by new power relations after COVID-19 also occur in the area of election administration policy, as discussed earlier in the IDEA summary (2020) regarding the threat of inclusiveness in the aspect of election participation. Furthermore, the writings of James \& Alihodzic, (2020) how the implementation of elections in a pandemic period requires assessment and evaluation based on the democratic concept of electoral integrity, not just adhering to international legal principles and practices that are institutionalized in global politics. When in different circumstances such as this crisis or disaster, the integrity of elections has the potential to be excluded from the institutionalization of the established election administration. Big threats to opportunities for deliberation, contestation, participation, and the quality of election management are challenges in holding elections in the midst of a disaster emergency such as the COVID-19 pandemic. 


\section{(De)politization Strategy in Agenda Framing Policy}

Public accountability is important for decision making process, especially during pandemic crisis. As stated by Flinders (2011), too much accountability has similar problems with less accountability during crisis, since COVID-19 could bring administrative problems in democratic governments, called Multiple Accountability Dis-order. Koppell (2005) mentioned five categories of them transparency, liability, controllability, responsibility, and responsiveness. Confusion in multiple accountabilities occurs when organizations cannot be accountable in various dimensions, such as emphasizing the demands and desires of the principal / ruler (controllability) and subordinating the demands and needs of constituents (responsiveness) and so on (Dewi \& Parwiyanto, 2018). When there are many channels of accountability that have to be accounted for by politicians, then it does not produce a frequency that is more blame-oriented than focused on understanding (Flinders, 2020b).

By postponing Regional Election, the government hopes that COVID-19 spreading can be managed well, but current record showed increased case and thus raising public awareness. Pros and cons on whether the election should be held or not is captured both in several reports from research whom focused on public opinion analysis based on digital media and social media trends in Twitte, such as Big Data Laboratories PolGov UGM (Polgov, 2020).

1. The postponement election has significant public attention, seen from the sizeable media coverage of online media and social media Twitter, as many as 3,746 articles from 155 media portals and 52,734 Tweets covering the topic of postponing the 2020 Simultaneous Elections

2. During the reporting period, there were two peak intensity discussions regarding the postponement of the elections in online media, namely, March 31, 2020 (after the agreement to postpone the 2020 Pilkada) and September 21, 2020 (after Muhammadiyah and Nahdlatul Ulama (NU) gave official statements not to carry out the elections in pandemic)). Furthermore, the highest trend for postponement of regional elections on social media Twitter occurred on September 21, 2020.

Based on this report, PolGov UGM assumed that public trust is remain low on government decision in holding election during pandemic. It also supported by statement from NU and Muhammadiyah as the representatives of civil society organization who respond in similar tone. Based on Social Network Analysis (SNA) report from Drone Emprit Academy (2020) it also mentioned that government decision to held election increase public debates on Twitter even though the government stated it will be followed by tight health protocols. Kuskridho Ambardi in his article "Penyelenggaraan Pilkada Serentak 2020: Aplikasi Prinsip Fairness di Era Pandemi", also highlighted the notion of two objectives in continuing elections during pandemic, i.e: Elections has not exacerbated the spread of the COVID-19 outbreak and at the same time, the largest social event in democratic life involving mass citizens continues to fulfill the standard of integrity in administering elections.

During the debate to decide on the implementation of Pilkada during a pandemic period, the most difficult to determine is when the spread of COVID-19 will end, this has led to difficulties in designing a definite timing for scheduling the elections (Fernandes, 2020). Even though the implementation of the Pilkada 
has been postponed from the due schedule, which is 23 September 2020, several experts from both academics and NGOs have doubts that the Pilkada can be held in December 2020, apart from the readiness of the election organizers besides that the trend of COVID-19 cases in Indonesia is not yet possible. Several scenarios that are considered ideal, such as postponing one year of the Pilkada implementation or a moderate scenario, namely delaying until March 2021 (6 months) (Fernandes, 2020), are not an option by the Government which focuses on the argument that no single authority can confirm when COVID-19 ends and therefore both scenarios are invalidated.There are two main problems faced by the government and especially by the election organizers, that is to hold the election with integrity and to arrange activities that do not exacerbate the spread of COVID-19. To get to the policy agenda level and finally decide on the implementation of Pilkada 2020, the government decided to politicize Pilkada 2020 and depoliticize COVID-19 health problems. The construction of threats regarding some unwanted risk when the election if elections are not implemented, can be seen on a government narration who mentioned the unwillingness of 270 regions carrying out Pilkada 2020 being led by the Acting Officers (Plt). As stated by the Coordinating Minister for Political, Legal and Security Affairs, Mahfud MD, as follows:

"... (in the midst of COVID-19 pandemic) the government does not want to let regional government only being led by Acting Officer in 270 regions in the same period" (Yahya, 2020).

The effort of politicizing the urgency of Simultaneous Regional Elections is creates by highlighting a political vacuum of power condition in regional level by the presence of Acting Officers. This argument is somehow questionable because the legal framework for legitimacy and authority of Acting Officer already has already exist. Besides, the government had a long experience in practicing it and has long list of qualified human resources for this position (Djohan, 2020).

The government's argument also has paradoxical effect with the plan for elections in 2024 which will also face the needs of Acting Officer. Even the government already has clear regulatory rules written in law. The revision of Regional Election Law is decided to move forward the simultaneous election from 2027 to 2024, so there will be 272 regions whose regional heads will be replaced temporarily by Acting Officer. In 2022 there are 101 regional heads who end their tenure and 171 officials who will end their tenure in 2023. The government's inconsistency has created many connotations and of course and increase the government's efforts to depoliticize legal provisions, as a form of definite political agreement.

Further case of depoliticization efforts are cases of COVID-19 has not been fully controlled since it only interpreted as being limited into the compliance of health protocols. The adoption of COVID-19 protocol also contains complexities that will affect aspects from participation and contestation, as elaborated by Ambardi, (2020). Ambardi explained the three levels of effect for adopting the COVID-19 protocol, those are individuals, social groups, and structures. The COVID-19 pandemic has also created new insecurities that impact minorities and create new gaps in power relations, since COVID-19 can attack anyone, but the impact was felt discriminatory because not everyone has the same experience (Carlà, 2020). Indicatively, this article explains that the consequences of Regional Elections and pandemic are holding Regional Elections in a "healthy" and secure way (Anggraini, 2020). 
The weight of "threat infrastructure" in the case of holding elections during pandemic era is the increased possibility of election's malpractice, especially rule making immaturity in its implementation. There is an impression that the Government is forcing to enact Government Regulation in lie of Law No. 2 of 2020 as a legal basis in organizing Pilkada but do not adequately responsive to solve problem in pandemic situation. The possibility of malpractice in Pilkada 2020 is increasing since there are so many potentials for violating regulation at each stage (Nurhasim, 2020). A study on the potential for malpractice in 2020 Election published by the Department of Government Politics, Faculty of Social and Political Sciences of UGM on the basis of object-based election i.e.: manipulation of election legal framework, manipulation of voters' choice, and manipulation of electoral administration. Furthermore, there are several potential malpractices in postponing elections which are prone to happen if there is no legal certainty in local elections, such as: limited budget; campaign arrangements; regulatory process' manipulation; voters; data and participation problems; election logistics and; incumbent's behavior (Karim, 2020).

As mentioned at the beginning, structural threats are sometimes more latent character, and in this case related to maintaining election's integrity. When monitoring election integrity is difficult and rarely receives tight public attention, the role of media (both digital and mass media) has pivotal role not only constructing collective insecurity but also establishing public awareness about the existing threats. Meanwhile, political leader will construct a collective threat, and turns out to be an interpretation of risk whom became a rationale for society in deciding their response (Kasperson et al, 2003 in Beland, 2007). Under the expected conditions, collective insecurity will affect a large part of the population and therefore may enter and influence the policy agenda.

In moments of crisis there is a tendency for politicians to pursue avoiding-blames strategy rather than claiming credit, since it has more reactive political behavior and often carried out by politicians. However, the government's efforts to advance the 2020 Pilkada agenda during a pandemic can be categorized as credit claiming strategy, since it has the goal of changing public opinion during crisis. Thus, a counter strategy was made to present a narrative with a positive tone to fight "negativity bias" (Weaver, 1986 in Hood, 2002). This strategy is shown in the statement of the Director General of Regional Autonomy of the Ministry of Home Affairs (Kemendagri) Akmal Malik,

"It has not shown any declining phase... We need masks, hand sanitizers, washing hands, many things. How to persuade people to do this? (There is) an election event, could be encourage people to comply with protocols. health, " (Purnamasari, 2020).

Meanwhile, avoidance-blame strategies are more related to politics of insecurity and how political authority constructs collective threats. In the institutional level, this strategy is directed at depoliticizing problems and sharing responsibilities. The efforts to depoliticize Pilkada 2020 can be seen from the coordination between the Government, DPR (House of Representatives) and KPU (General Election Commission) in making laws and regulations during pandemic. They depoliticized the regulatory process which should be carefully prepared for strong legal certainty for the safety of the parties and maintaining its integrity. 
Representation from civil community who is also a member of the 2012-2017 KPU Commissioner Gumay, (2020) argue that the existing legal framework is not designed for elections with certain complexity caused by a pandemic. For example, in terms of the characteristics of the elections' implementation. Second, reversed logic is used in drafting regulations since the existing laws have not regulated the implementation of local election during pandemic. Instead of creating the adequate legal framework first, the government rely on PKPU (General Election Commission Regulation) whom its legal position is lower than Law. Thus, if the government has willingness to put integrity as pivotal values in holding election during pandemic, the earliest step is establishing comprehensive regulations to mitigate potential fraud during election. Ideally, a certain process is needed to revise the Law, and then in order to provide sufficient legal framework for election during pandemic, it should be supported by more technical regulation in the scope of electoral management body.

\section{Conclusion}

Political authorities construct and creates collective threats to increase awareness in public, and thus affect public policy. Increasing level of risk awareness is capable to decrease the expansion of state protection. This study concludes that state protection is highly dependent on the existence of threat infrastructure in specific policy areas. Besides, political authorities have limited power to maintain policy accountability in all level. During Pandemic era, there are two objectives of holding Simultaneous Regional Elections i.e. election activities do not increase the spread of the COVID-19 outbreak; and at the same time still fulfil electoral integrity and accountability standardsIn the same times, the existence of COVID-19 can be cross-contaminated with social and economic conditions that threaten not only human safety but also create new democratic crises. It can lead to pathologies in democracy and create political blaming among political authorities. 


\section{References}

Amalia, N. (n.d.). Tok! Disepakati Hari H Pilkada Serentak 20209 Desember 2020. Perludem. http://perludem.org/2020/04/14/tok-disepakati-hari-h-pilkada-serentak-2020-9-desember-2020/

Anggraini, T. (2020). Evaluasi Integritas Pilkada Tahun 2020 di Tengah Pandemi Covid-19: Tinjauan Beberapa Isu Krusial. In DKPP RI. https://www.youtube.com/watch?v=adduNbd6idg\&t=5868s

Beland, D. (2007). Insecurity and Politics : A Framework Author ( s ): Daniel Béland Source: The Canadian Journal of Sociology / Cahiers canadiens de sociologie, Summer, Insecurity and Politics: A Framework1. 32(3), 317-340.

Béland, D. (2010). Reconsidering policy feedback: How policies affect politics. Administration and Society, 42(5), 568-590. https://doi.org/10.1177/0095399710377444

Brändström, A., \& Kuipers, S. (2003). From "normal incidents" to political crises: Understanding the selective politicization of policy failures. Government and Opposition, 38(3), 279-305+i. https://doi.org/10.1111/1477-7053.t01-1-00016

Buzan, B., Waever, O., \& Wilde, J. de. (1998). Security: A New Framework for Analysis. Lynne Rienner Publisher, Inc.

Carlà, A. (2020). A new kind of insecurity: how the pandemic has affected minorities. Blog LSE. https://blogs.lse.ac.uk/covid19/2020/07/21/a-new-kind-of-insecurity-how-the-pandemic-has-affectedminorities/

Christopher Hood. (2002). The risk game and the blame game. Government and Opposition, 31(1), 15-37.

CNN Indonesia. (2020, September 21). Jokowi Tegaskan Pilkada Tak Akan Ditunda. CNN Indonesia. https://www.cnnindonesia.com/nasional/20200921115529-32-548867/jokowi-tegaskan-pilkada-takakan-ditunda

Denney, A. S., \& Tewksbury, R. (2013). How to Write a Literature Review. Journal of Criminal Justice Education, 24(2), 218-234. https://doi.org/10.1080/10511253.2012.730617

Dewi, Y. K., \& Parwiyanto, H. (2018). Multiple Accountabilities Disorder in a Study of Grant and Social Assistance Budgeting in Surakarta. Spirit Publik, 13(2), 47-61. https://doi.org/10.1088/1751$8113 / 44 / 8 / 085201$

Dhucarme, J. (2020, March 11). World Health Organization Declares COVID-19 a "Pandemic." Here's What That Means. TIME.

Djohan, D. (2020). Penyelenggaraan Pilkada di Era Pandemi. Djohan, Djohermansyah

Drone Emprit Academy. (2020). PILKADA 2020 - PRO \& KONTRA. Drone Emprit Publication. https://pers.droneemprit.id/pilkada-2020-pro/

Fernandes, A. (2020). COVID-19 dan Penundaan. CSIS Commentaries, 3 April, 1-5.

Fernandez, A. (2020). Pilkada 2020: Ditunda, Lalu Bagaimana? https://www.youtube.com/watch?v=m6jn2EEH_1M

Flinders, M. (2011). Daring to be a Daniel: The pathology of politicized accountability in a monitory democracy. Administration and Society, 43(5), 595-619. https://doi.org/10.1177/0095399711403899

Flinders, M. (2020a). Democracy and the Politics of Coronavirus: Trust, Blame and Understanding. 
Parliamentary Affairs, 1-20. https://doi.org/10.1093/pa/gsaa013

Flinders, M. (2020b). Gotcha! Coronavirus, Crises and the Politics of Blame Games. Political Insight, 11(2), 22-25. https://doi.org/10.1177/2041905820933371

Fraenkel, J. R., \& Wallen, N. E. (1990). How to Design and Evaluate Research in Education, 8th Edition.

Gumay, H. N. (2020). Mengapa Pilkada Perlu Ditunda? https://www.youtube.com/watch?v=s2Mk2hxV25A

Hanif, H. (2020). Para politkus Indonesia saling lempar kesalahan dalam penanganan COVID-19. The Conversation. https://theconversation.com/para-politikus-indonesia-saling-lempar-kesalahan-dalampenanganan-covid-19-145543

Huysmans, J. (2006). The politics of insecurity: Fear, migration, and asylum in the EU. In The Politics of Insecurity: Fear, Migration and Asylum in the EU. https://doi.org/10.4324/9780203008690

IDEA. (2020). of Democracy Taking Stock of Global Democratic Trends Before and During the COVID-19 Pandemic. December.

James, T. S., \& Alihodzic, S. (2020). When is it democratic to postpone an election? elections during natural disasters, covid-19, and emergency situations. Election Law Journal: Rules, Politics, and Policy, 19(3), 344-362. https://doi.org/10.1089/elj.2020.0642

Kalpokas, I. (2020). The Biopolitics of COVID-19: The Pure Governmentality of Life. 6.

Karim, A. G. (2020). Mencegah Electoral Malpractice dalam Penundaan Pilkada policy brief on electoral politics. April.

Koppell, J. G. S. (2005). Pathologies of accountability: ICANN and the challenge of "multiple accountabilities disorder." Public Administration Review, 65(1), 94-108. https://doi.org/10.1111/j.15406210.2005.00434.x

LIPI, H. (2020). Melihat Jepang, Menerapkan Strategi Tiga Pilar Utama dan Menghindari 3C untuk Penanganan COVID-19. LIPI. https://ipsk.lipi.go.id/index.php/berita/719-melihat-jepang-menerapkanstrategi-tiga-pilar-utama-dan-menghindari-3c-untuk-penanganan-covid-19

Marshall, C., \& Rossman, G. B. (2016). Designing Qualitative Research (Sixth Edition). Sage.

Mas'udi, W., \& Winanti, P. S. (2020). New Normal: Perubahan Sosial dan Politik Akibat COVID-19. In Gadjah Mada University Press (Vol. 58, Issue 12). https://doi.org/10.1128/AAC.03728-14

Nurhasanah, S. (2020). Covid-19 As A Non-Traditional Threat To Human Security. Journal of Strategic and Global Studies, 3(1). https://doi.org/10.7454/jsgs.v3i1.1028

Nurhasim, M. (2020). Dampak Pandemi COVID-19 Terhadap Pilkada 2020. LIPI. http://www.politik.lipi.go.id/kolom/kolom-2/politik-nasional/1398-dampak-pandemi-covid-19terhadap-pilkada-2020.

Polgov, U. (2020). Meneropong Kelanjutan Pilkada Serentak di Tengah Pandemi. https://polgov.fisipol.ugm.ac.id/riset/meneropong-kelanjutan-pilakada-serentak-di-tengah-pandemi

Priyasmoro, M. R. (2020). Evaluasi Pilkada Saat Pandemi Covid-19, Perludem Minta Aturan UU Pemilu Dibuat Adaptif. Liputan 6. https://www.liputan6.com/pilkada/read/4431879/evaluasi-pilkada-saatpandemi-covid-19-perludem-minta-aturan-uu-pemilu-dibuat-adaptif

Purnamasari, D. M. (2020). Kemendagri: Pmerintah Yakin Pilkada Bisa Jadi Alat Melawan COVID-19. 
Kompas. https://nasional.kompas.com/read/2020/09/23/15354841/kemendagri-pemerintah-yakinpilkada-bisa-jadi-alat-melawan-covid-19

Roberts, D. (n.d.). Global Governance and Biopolitics: Regulating Human Security. 634.

Sears, N. A. (2020). The Securitization of COVID-19: Three Political Dilemmas. Global Policy Journal. https://www.globalpolicyjournal.com/blog/25/03/2020/securitization-covid-19-three-political-dilemmas

Weaver, K. R. (1986). The Politics of Blame Avoidance Author ( s ): R . Kent Weaver Published by: Cambridge University Press Stable URL : http://www.jstor.org/stable/4007281 Accessed : 21-08-2016 17 : 16 UTC The Politics of Blame Avoidance *. Journal of Public Policy, 6(4), 371-398.

Yahya, A. N. (2020). Pilkada 2020 Tetap Digelar, Mahfud: Pemerintah Tak Ingin Ada Kepala Daerah Plt. Kompas. https://nasional.kompas.com/read/2020/09/22/15340721/pilkada-2020-tetap-digelar-mahfudpemerintah-tak-ingin-ada-kepala-daerah-plt?page=all

Yanuarti, S. (2020). Evaluasi Manajemen Krisis Negara dalam Penanganan Pandemi COVID-19. LIPI. http://www.politik.lipi.go.id/kolom/kolom-2/politik-nasional/1402-evaluasi-manajemen-krisis-negaradalam-penanganan-pandemi-covid-19

Zahariadis, N., Petridou, E., \& Oztig, L. I. (2020). Claiming credit and avoiding blame: political accountability in Greek and Turkish responses to the COVID-19 crisis. European Policy Analysis, 1-11. https://doi.org/10.1002/epa2.1089 